\title{
Role and Liability of the Auditors in the Eu and in China: From Supervision Perspective
}

\author{
$\mathrm{Hu}$, Ruichao ${ }^{1}$ \\ ${ }^{1}$ China University of Political Science and Law, Beijing, China \\ Correspondence: Ruichao Hu, Law School, China University of Political Science and Law, Beijing, Haidian \\ District, Xitucheng Road NO. 25, China. Tel: 86-188-1062-3997. E-mail: Ruichaohu@163.com
}

Received: October 2, 2015 Accepted: November 1, 2015 Online Published: November 23, 2015

doi:10.5539/res.v7n12p170 URL: http://dx.doi.org/10.5539/res.v7n12p170

\begin{abstract}
False financial statements have been found in audit report recently. How to prevent fraud and protect investors and debtors becomes more important. The key issue is to define the role of auditors in audit service. It shall be analyzed from multiple perspectives. The liability of auditors is another critical issue, which is consecutive part to the first issue. The second issue would be the relief procedure for investors. If this procedure functions well, it could strengthen the effectiveness of the audit regime. This thesis would discuss these issues from comparative perspectives: the EU and China. Since the legal background and economic development are different, the effect of same regime may differ a lot. This is what this thesis tries to reveal.
\end{abstract}

Keywords: audit service, role, liability, EU, China

\section{Introduction}

In recent years, the capital market witnesses a series of domestic and international financial scandals. More and more illegal auditing activities were disclosed in the same breath. Auditors, providing audit service for the company and being as "gatekeepers" for the government to supervise the market, are the persons who should be independent and impartial. However, cases such as Enron, Worldcom, Xerox and so on notice the public that even under the most transparent supervision system, it still cannot avoid the financial fraud, and the auditors, at most of time, help the audited company to make false financial statement. The internal controller of the company crazily makes financial fraud so as to get interest for himself, while the auditors always give a "pass" for the internal controller until the financial fraud has been revealed. In most cases, these listed companies, which have very good financial "appearance", always unpredictably go into debt or even bankruptcy. Why this phenomenon happens all the time? What is the role of the auditors when audit companies? What is the liability of the auditors if they make a false financial statement? To answer these questions is the purpose of this thesis.

There exist two kinds of auditors: external auditor and internal auditor. The formal one is required by the law to supervise the company so as to protect the potential investors and safeguard the market. The later one is employed by the company or by the management board in order to obtain self-control effect. This kind of auditor is always the company's stuff. Because the phenomenon we mentioned before refers to the independent audit service providers, and such as "Big Four" firms (Deloitte, Ernst, \& Young, KPMG and PwC) have more importance on the market, hereafter we focus mainly on the external auditor.

An auditor is employed to provide audit service. On the one hand, he has an employment contract with the company or the management board. The company gives a job opportunity to the auditor and the auditor shall work for the company. This is the requirement of the contract. Due to the nature of auditing is to supervise and scrutiny the company, the auditor shall behave as more independent and impartial as possible. Only in this way can the audit report be authentic and believable. This is required by the law. Obviously, there is a strong conflict of interest in this situation.

The role of auditor is controversial. Audit a company is a process, which evolves several participants including the audited company (the management board), the auditor, the government (or the supervisory body), the investors or shareholders and potential investors. In this process, everyone needs the audit report to know the true business and make a right decision. Therefore, the audit report is a very important document on the market. If we want the process to work well, there shall be a series of hypothesis: Firstly, the financial report provided by 
the company shall fairly present the true financial situation, profitability and cash flow of the company; Secondly, the auditor shall offer his statement independently and be due diligent during the auditing process (Article 173 of Securities law of PRC); Lastly, the supervisory body will rely on the audit report and promote such a report to the market to convince the shareholders and investors. These hypotheses are so sophisticated that even any part going wrong will totally makes the process collapse. The forehead hypotheses are theoretically. Practically, however, the assumed situations always fail to achieve. Also, the reputation system and information market theory have a great impact in this process. Since the regime of the market developed in China and EU are different, the result of the same system may differ.

Auditors have a direct legal liability to investors for any false and misleading statements or major omissions in an audit report (Johnston \& Parker, 2007). There exist two kinds of liabilities of auditor: liability based on a contract, and liability based on a non-contractual relationship. Liability based on contract relationship is a liability between auditor and the audited company. However, auditor can also be considered to be in the interest of shareholders and potential investors. In this case, the statutory audit provides the third parties, relying on the audited financial statements for investment decisions, with crucial information. This is called an auditor's non-contractual liability (Beckman \& Nass, 2007). This distinction of liability various from country to country and the development history of such a liability is very different in countries. Some countries do not have non-contractual liability of auditor. They solve this problem through tort law. The other countries solve this problem by expanding the scope of application of the contractual liability to the third party. Also, auditors' liability regimes can be strict liability and negligence-based liability. And there is a tendency to limit auditors' liability.

The article will proceed as follows. Section 2 describes the role of every participant on the auditing market and demonstrates the logic of development which may differ from China and EU. Section 3 describes the history of development of the liability of auditor and contemporary development in China and EU. Section 4 will be a conclusion of this article.

\section{The Role of Auditors}

Capital market is an information market where people transact the valuable securities containing valuable information. This information, the statement of financial situation, represents the profitability of the company. Between the transaction parties, the one who owns more information will make a right decision about the market, while those who lack of information always lose transaction opportunities. It may be caused by two reasons. On the one hand, participants are different. They have different abilities to collect available information on the market. On the other hand, social division gradually becomes more detailed, which makes a difference between the professional and the non-professional. Therefore, information asymmetry always exists (Xin, 2001). Moreover, information asymmetry is more obvious on the capital market. It is because the information on the securities represents future financial situation, which has a strong connection with the operation performance of company and outside circumstances. In other words, since this financial situation is always unpredictable, information on the securities to some extent presents whether the capital market can function efficiently or not (Wu, 2002).

If the market has information asymmetry, the "visible hand", i.e. the market itself, fails to operate its regulatory mechanism. Such a market does not have a sufficient competition, so that "survival of the fittest" mechanism may not work effectively. This will lead to two low-efficient results: lemon market (Akerlof, 1970) and internal controller. According to the lemon market theory, the seller (the company) knows the true quality of the products while the buyer does not. The buyer, however, would estimate the average quality of the products and offer an average price for the products. Under this circumstance, the higher quality products may be underestimated, so that the seller is not willing to sell such products. On the other hand, the lower quality products may be overestimated. As a result, the number of high quality products will decrease on the market while the low quality products will be more. If this hypothesis is true, the average price will be lower, which will conversely expel high quality products. This is the lemon market. As for the internal controller, although there are some researches arguing the active effect the internal controller has on the market efficiency (Beny, 2004), when analyzing the role of auditor, we hypothesized internal controller will lower the efficiency.

Under this circumstance, the third party, such as auditors, lawyers who provide intermediate service are quite important. They are professionals who may disclose necessary information to make the market more transparent. Therefore, we need discuss the role of auditor. Whether we can appropriately define the role of auditor would affect the efficiency of capital market. In audit activity, auditors are always at the center position. All other participants including the supervisory body, company (management board), shareholders and potential investors 
need audit report. Besides, auditors themselves have their own demands. Since auditors need to meet all the other participants' demands as well as their own ones, the relationship among the participants are quite complex. Therefore, we need to analysis the relationship between the auditor and each participant so as to demonstrate the role of auditor on the capital market.

\subsection{Shareholders and Potential Investors}

Shareholders and potential investors need auditors. Securities are special goods containing valuable information. It is the information that makes the securities valuable. For investors, they lack the knowledge and information of the company. Investors can not infer the future income of the business plan through inspect (Easterbrook \& Fischel, 1984).

If there is no audit report, investors have to investigate the financial matters by themselves. Obviously a single investor is hard to finish such kind of investigation. It will cost a lot, including money and time for collecting data. This is quite low-efficient transaction. Therefore, from the perspective of potential investors, they hope to authorize one auditor to provide information-collecting service.

When investors hold shares, they become shareholders. They also need audit service. In a company, the interests of shareholders and the interests of directors and managers are not always same. The management board and directors may have temptation to control the company for the interests of their own. In order to avoid this, shareholders, the real owners of the company, have the right to access business information and somehow supervise the board of managers and directors. Financial situation is a critical part that shareholders need to know. Internal auditors and managers have difficulty in keeping impartial. Therefore external auditors or independent auditors are required to provide audit service for all of shareholders.

Although there is no direct contract between auditors and shareholders or potential investors, the key to connect these parties is trust. If an auditor fails to meet his due diligence obligation, he may face several kinds of punishment: firstly, the shareholders and potential investors may initiate ligation for remedy; secondly, the market may produce a negative assessment of the auditor, which derogated from his reputation. It is hard for investors to trust this auditor in the future. In other words, the auditor may lose working opportunity. Lastly, the auditor may be deprived of the audit service license.

\subsection{Managers and Directors}

On the capital market, managers and directors know the companies' financial situation very well, but the investors do not. Some companies, especially those having good financial situation and a profitable business, are willing to disclose their financial information to the public. If they do so, they may get money from investors more easily. On the other hand, companies of bad financial situation may tend to beautify their financial statement so as to attract more investors. As a result, to avoid or mitigate the bad effect of lemon market, the company needs a third party, i.e. the auditor to be a gatekeeper.

A listed company needs a good reputation on the capital market. The company itself, however, is hard to obtain such a reputation. Since the managers and directors have a conflict of interest with the shareholders, shareholders are not easily convinced. Employing an auditor with good reputation is the most convenient way to solve this problem. On the one hand, setting up a good reputation needs a lot of time, money and energy. As for a company, it has its own business. It shall devote all the resource to that field. On the other hand, audit firms are more professional and care about their reputation. An audit report to some extent stands for a guarantee that the auditor offers by his own reputation.

An audited company has a contract with the auditor. The company makes the payment for the audit service. Good financial situation may not cause problems. The problem is, however, when the financial situation is not so good, can the auditor be impartial enough to offer a financial statement? Managers and directors hope the financial statement can be beautified so as to get more investment. If the auditor refuse to beautify such statement, the company may go worse. In order to avoid this, the managers may threat the auditor by stopping the audit service contract and changing auditor firms. Under this circumstance, the auditor is hardly to keep independent.

\subsection{The Supervisory Body}

The government or the supervisory body needs the auditors to supervise the company and protect the market. As a statistic reveals, every year more than 100 companies applying for IPO and at present there exist more than 2000 listed companies in China (Note 1). It is a tough work for the supervisory body to supervise so many companies. Thus a third party is needed. For the supervisory body, they can mitigate work load and decrease supervising cost. For auditors, they could obtain work opportunity. If an auditor fails to fulfill his obligation and 
makes some false statements, the supervisory body would sue the auditor. It is much easier for the supervisory body to supervise auditors than the companies, because the supervisory body controls auditors' licenses. Supervising the numerous companies needs more time and energy. The supervisory body can deprive auditor's license, if the auditor makes a false statement in an audit report.

\subsection{Supervision Regulations Relevant to Auditors}

Chinese Auditing service began to expand in 1980s. Meanwhile Chinese government began to set up the CPA regime to regulate auditors. From the historical perspective, supervision regulations relevant to auditors could be featured by four steps (Cai, 2006):

A. 1980-1988 Interim Provisions on the Establishment of Accounting Consultants Offices (1980) was entered into force permitting Accounting Consultants Offices (namely CPA Firms at that time) to be set up. Together with Regulations of the PRC on Certified Public Accountants (1986), the Chinese Ministry of Finance was directly in charge of CPA firms as well as their employees.

B. 1988-1993 The Chinese Institute of Certified Public Accountants (“CICPA"), as an affiliated part of Ministry of Finance, was founded and began to regulate auditing services through authorizations of Ministry of Finance.

C. 1993-2001 Law of the PRC on Certified Public Accountants (1993), to some extent, authorized CICPA to be a self-regulatory body to regulate CPA firms and CPA.

D. After Enron, administrative agencies strengthened supervision on auditors.

Therefore, there are two tiers of supervision relevant to auditors. On the one hand, governmental supervision involves Ministry of Finance, National Audit Office, China Securities Regulatory Commission, etc; on the other hand, CICPA, as self-regulatory body, also supervise auditing activities. However, this mechanism is problematic Since the CPA regime was guided and promoted by administrative power, the industry itself lacks experience and motives to be self-regulated. Besides, too many administrative agencies involved in supervision may reduce efficiency.

On the EU level, Directive 2006/43/EC has played an important role in supervision relevant to statutory audit. It declared to create a Committee on Auditing which would supervise the fulfillment of International Standard on Auditing ("ISA") in the EU member states. Besides, it required to organize an effective system of public oversight for statutory auditors and audit firms. From the perspective of supervisory agencies, the EU level has two major agencies relevant to supervision on auditing. The first one is the Audit Regulatory Committee, which is formed by delegates from member states. This agency assists the Commission of EU to regulate auditing through Comitology. The European Group of Auditors' Oversight Bodies ("EGAOB") is the second agency which helps to supervise auditing under public oversight on the basis of home country control. The supervisory regulation on the EU level is different from a domestic one. Also, it is different from Chinese supervisory regime.

\subsection{The Difference between China and EU}

The statement above is a description of the audit procedure. Whether it can function well shall take the market circumstance into consideration. Since China and EU have different backgrounds as well as audit regime histories, the real effect may differ.

The market economic only exists 30 years in China since the "Reform and Opening Policy". Many regimes are designed by the government, not developed by the market itself. As for the audit regime, it is established by several laws (Note 2) and regulations (Note 3) after 1979. Later, when Shanghai Stock Exchange was established, Shanghai Interim Measures of Stock Management (Art.9; Art.10; Art.21.) was passed, which at first time mandatory required external audit. In 1994, the State Council passed Interim Provisions on the Management of the Issuing and Trading of Stocks(Art.12; Art.13; Art.15; Art.32; Art.33.), which formally set up the mandatory external audit regime. This was also recognized by Company Law and Securities Law. Contemporarily, laws and regulations of mandatory external audit would be summarized as follows:

A. When a company applies IPO or offer new shares, it shall have an audit report in advance. If the issuer makes profit forecast report, it shall obtain an audit report (Note 4).

B. The financial report contained in the prospectus shall be audited by external auditor (Note 5) .

C. The financial report contained in the semi-annual report shall be audited by external auditor (Note 6).

D. The annual financial report of the listed company shall be audited by external auditor (Note 7). 
E. Others items, for example, in M\&A, submitting an external audit report is needed (Note 8).

The aforementioned is the Chinese audit regime. Practically it may not work well. On the one hand, most listed companies are state-owned companies, which may have the obligation to maintain the social stability. Actually the Chinese capital market is designed for the state owned companies to reform (Zhang, 2010). IPO is a good way to attract investment, therefore these companies' target is to beautify the financial situation and get more money. The logic behind the legislation is that if laws regulate mandatory external audit, false financial statement could be avoided, otherwise the auditor would be liable for this. However, local governments, in order to create fortune and working opportunity, would assist local state-owned companies to apply IPO. More often, local governments assist to make false financial statement (Jiang vs. PT Hong Guang and Chen Du Su Du CPA Firm, 1998). The audit regime was mandatorily set up by administrative power which may differ from those developed by the market itself. Auditors' target is only to meet pro forma financial requirement. If they fail, they would be changed. It happens in China frequently (Wang, 2002).

Differently, Member States of EU has a long history of market economy development. Market competition would be more effective. As for the modern audit regime, in most EU countries a company would decide whether they need an audit report by itself, i.e. it is not mandatory. Before 1900, financial statement was a private business for a U.K. company, thus law could not intervene (Chatfield, 1989). However, most companies were willing to obtain an external audit (Davies, 1997). It is because those who have external audit reports are more easily be trusted by the public. Although after 1900 the English Company Law (1929) mandatorily required external audit report, submitting a prospectus with an external audit report has become a usage. In 1994, the legislation body canceled the mandatory requirement of external audit report for micro companies. In Germany, external audit was not mandatory before 1930. Affected by the U.K., Germany government enacted Verordnung des Reichsprasidenten über Aktienrecht, Bankaufsicht und über eine Steueramnestieund in 1931, which required mandatory external audit to strengthen supervision.

All in all, most EU countries have a long history of market economic since the industry revolution. They have a long period for the market to develop by itself without governments' intervene. Self-regulatory spirit and organizational arrangement could be developed during such a progress. As a result, submitting external audit report is a market choice. If a company could provide an external audit report to the public, it would attract more attention. This could help the company to obtain investment. China has different background of such development. Besides, state-owned companies need to raise money from the market. These facts contribute to making Chinese audit regime ineffective.

\section{The Liability of Auditors}

\subsection{Contract Liability and Non-Contract Liability}

Auditors' liabilities can be classified as contract liability and non-contract liability. Contract liability means an auditor has a contract with the audited company, for which the auditor would be liable if he fails to fulfill his obligation. As for non-contract liability, considering auditor offers third parties crucial information for investment decision-making, the auditor has a duty of care towards the audited company and third parties. It is not governed by contract. Third parties can ground the liability action in tort (Beckman \& Nass, 2007). In some countries, like the U.K., auditors' liability is a non-contract liability, which means it is regulated by tort law. In other countries, like Germany, auditor's liability is a contract liability, which may be expanded to the third party. In most EU Member States, if auditors are held liable for a third party, the third party shall prove that the auditor have breached their duty of due care. In Vie d'Or case (Netherlands), the Supreme Court of the Netherlands holds that an auditor's duty care was not limited to interests of the audited company.

In the U.K., one person, traditionally, would not constitute an infringing act solely due to negligence. An infringing act would be formed when a person breaches duty of due care that laws regulate. As for auditors' liability, since no contract between the auditor and the third party, the auditor is not liable. For negligence, in the Hedley Byrne case, the British caselaw established the rule that the professional would be liable for the third party if he made a negligence misrepresentation. It expands the scope of infringing liability for solving this problem. A third party may rely on an auditor when he reads the financial statements. This reliance liability is to protect public interest. If the auditor fails to fulfill his reliance obligation, he would be liable for the third party.

In Germany, auditors' liability for a third party is a difficult problem. It is because the German Civil Code recognizes that auditors are only liable for clients who have contracts. However, in judicial practice, the court expands the contract liability to third parties. Three ways have been found. Firstly the professional has a contract liability for supplying implied information, which means he is liable to a third party. The second one is that the debtor to the contract shall owe duty of care to the third party according to the principle of honesty and 
credibility. The third one is the liability of culpa in contrahendo. The last way has been recognized by the new Civil Code which states: "An obligation with duties in accordance with Article 241 (2) may also arise towards persons who are not intended to be parties to the contract. Such an obligation arises in particular if the third party by enlisting a particularly high degree of reliance materially influences the contractual negotiations or the conclusion of the contract." And Article 241(2) regulates: "An obligation may require each party to have regard to the other party's rights, legally protected interests and other interests." (Note 9).

In China, it is not clear whether auditors' liabilities shall be based on Tort Law or Contract Law. Article 39(1)(2) of Law of Certified Public Accountants regulates the liability of auditor and auditor firms. Article 42 regulates the liability of CPA firms. Also the Securities law regulates the auditors' liability by Article 171 and Article 173. From these Articles, we could find that auditors are liable for their false financial statements. However, it is still not clear whether it is based on contractual liability or non-contractual liability. In 2002, the Supreme People's Court seems to give its opinion in Notice of the Supreme People's Court on the Relevant Issues concerning the Acceptance of Cases of Disputes over Civil Tort Arising from False Statement in the Securities Market. Supreme People's Court considered that the false statement was a tort issue. In 2003, the Supreme People's Court promulgated Some Provisions of the Supreme People's Court on Trying Cases of Civil Compensation Arising from False Statement in Securities Market, which also agreed this conclusion. Through this analysis, we may infer that in Chinese judicial practice, the court attempts to recognize the false statements as a tort issue.

Besides, liability could be classified as strict liability and negligence-based liability. These two liabilities are adopted in different countries. It varies from different legal backgrounds, economic development situations, the development levels of audit market, etc. Mostly, negligence-based liability is in principle position while strict liability is a supplement one. It is recognized by Chinese law (Note 10) and laws within EU Member States.

\subsection{Allocation of Liability}

An auditor provides audit service on the market. Financial statement would be a document instructing investors. However, the misrepresentation in the financial statement may cause damage for the investors. How to discriminate the liability between the auditor and others is difficult.

The first proposition is that the auditor shall have several and joint liability. It means two or more parties are liable to the creditors. Several and joint liability can sufficiently protect the investors. Creditor could require the auditor to pay all the damages. If the company is not in good financial condition, creditors would directly sue the auditor. Such proposition was adopted by Chinese judicial practice. In 2003, the Supreme People's Court gave an interpretation stating "securities trading service institution...makes a misrepresentation ...bear several and joint liability". Besides, it is also recognized by Article 173 of the Chinese Securities law.

The second proposition is to distinguish intentional fault, culpable negligence and general negligence, applying several and joint liability as well as shared liability respectively. When the auditor has an intentional fault or a culpable negligence, several and joint liability applies. Auditor only bears shared liability if he has a general negligence. This proposition is recognized by the U.S. and most EU Member States. In the U.S., Private Securities Litigation Reform Act (1995) recognized the proportional liability for the auditor when he only has general negligence. In the EU, for example, Netherlands, also adopts this proposition. The Supreme Court of Netherlands gave a judgment in the Vie d'Or case, which states that "auditors are only proportionally liable for wrongfully issuing an auditor's report of approval concerning annual accounts of 1989, 1990, 1991 and 1992 \& of inadequate provision of information."

\subsection{Liability between Auditor and Audit Firm}

Liability between auditor and auditor firm also needs to be discussed. Here, "auditor" means the one that providing audit service for the audited company. "audit firm" means the firm which the auditor belongs to.

The liability regime is not fully harmonized in the EU. In 2006, 16 of 25 Member States implemented a combination of specific rules applying to auditors' liability on top of an existing general civil liability system (Commission Staff Working Paper, 2007). In some Member States only the individual auditor can be liable for the damage. That means the audit firm will not be liable. Ireland is an example. In the other Member States, both the individual auditor and the audit firm he belongs to shall bear the liability. It is a several and joint liability between the individual auditor and the audit firm.

In China, liabilities between the individual auditor and the audit firm are not clearly discriminated. It could only be found that audit firms are liable, while auditors' liabilities are not mentioned. Furthermore, Chinese Company Law, Securities law as well as Supreme People's Court Interpretation only require audit firms to bear the liabilities. Law of the PRC on Certified Public Accountants also requires the firm to bear the liability. Under 
this circumstance, the actor and the liability bearer are separated in the audit service infringement. According to the employment relation between an individual auditor and the audit firm, the firm shall pay the damage first when the damage happens. However, it is not clear whether the audit firm, after paying the damage, obtains the right of recovery under Chinese law. If the misrepresentation is the individual auditor's fault, it is unfair for the firm to bear all the liability. The firm may bear part of liability if there is a misrepresentation, the individual auditor who has fault shall bear the other part of liability.

\subsection{Limitation to Liability}

When an auditor issues a financial report, it can be accessed by numerous investors. If all the investors, relying on the financial report and making a wrong decision, require recover from the auditor, it is not reasonable. Limitation to auditor's liability develops. However, several researches indicating that audit service quality may be affected if there is a liability cap (Chan \& Pae, 1998). As for audit firms, they are arguing that set a liability cap when there is a damage to investors will not lead to lower quality audit service (Napier, 1998). Since this is debated, legislators, scholars and professionals shall take it into deep consideration. Besides, organizational forms of audit firm and audit quality may have some connections. This is recognized by some researches (Firth, Mo, \& Wong, 2012), which indicate that auditors in a partnership audit firm incline to report more conservatively than auditors in a limited liability audit firm do. This research is based on Chinese audit market, however, it could also reveal some problems outside China. Although there are so many different voices for the audit liability cap, this regime has been recognized by many countries, including several EU Member States.

There are five EU Member States have capped the auditors' liability. They are Austria, Belgium, Greece, Germany and Slovenia. Austria caps the liability per audit. For a statutory audit of a small or medium-sized company the cap is 2 million euros, for large companies a 4 million euros is established. On the other hand, auditors' liability is capped at 8 million euros for audits of companies with size characteristics fivefold the size characteristics for large companies, and capped at 12 million euros for audits that are tenfold the size of a large company (Beckman \& Nass, 2007). In Belgium, the caps for the unlisted companies and listed companies are different. For the unlisted companies, the cap is 3 million euros, while for the listed ones, the cap is 12 million euros. In Greece, the cap per audit is " 5 times the total annual emolument of the president of the supreme court or the total of the fees in previous years" (Beckman \& Nass, 2007). In Germany, the cap varies from 1 million euros to 4 million euros per audit. It depends on whether the company is listed company or unlisted company. In Slovenia, the cap is set at 150,000 euros.

In China, before 1998, all the audit firms were state-owned. They were affiliations of administrative body. Thus, audit firms were not separate legal entities, which meant they did not need to bear liability. The revolution began after 1998. All the state-owned audit firms shall be separated and became independent legal entities (Yi, 2003). Obviously, audit firms shall bear the liability by themselves after this revolution. In order to alleviate financial loss, policy makers set some caps for auditor's liability. The liability shall not exceed the maximum liability that is caused by reliance. For example, an investor bought 10,000 yuan stocks due to reliance of the financial statement. If such a financial statement is false, the shares' value only amont to 5,000 yuan, the liability of misrepresentation shall be 5,000 yuan. In Chinese judicial practice, the liability shall be limited to the number of false statement part. It can be found in Supreme People's Court Decision (1996) No.56, Supreme People's Court Interpretation (1997) No.10, and Supreme People's Court Interpretation (1998) No.13.

\section{Conclusion}

The thesis compares the role of auditor in the EU and China. Both laws require mandatory external audit. However, the logic and background behind are different. Since China developed market economy only 30 years, it is not perfect enough. Mandatory external audit regime was not self-generated, but was requested by the supervisor. Therefore, an auditor seems to be a certification of satisfying the appearance requirement of the supervisory body, but actually the financial statement may still involve misrepresentation. In the EU, external audit is a result of historic development. It has its social and legal background. Companies with financial statements would be more attractive to investors. Thus, the companies are willing to employ the auditor to provide audit service.

Next the thesis compares the auditor's liabilities in the EU and China. Firstly, there are contract liability and non-contractual liability. Both can solve the problem. In China, the judicial practice may tend to recognize the liability as non-contractual liability. Secondly, it compares the several and joint liability and shared liability. Chinese law recognizes the former one. Thirdly, it distinguishes the liability between the individual auditor and the audit firm. In the EU, Ireland is an exception that only considers the individual auditor can be debtor. The other Member States recognize the individual auditor as well as the audit firm can be liable. In China, laws only 
recognize audit firms could be liable. But it may seek to recover from the individual auditor. Lastly, it explains the limitation to liability. In the EU, there is a cap to the limitation. It varies from country to country. In China, there is also a limitation that limits the scope of liability.

\section{References}

Akerlof, G. A. (1970). The market for" lemons": Quality uncertainty and the market mechanism. The Quarterly Journal of Economics, 488-500. http://dx.doi.org/10.2307/1879431

Beckman, H., \& Nass, E. C. (2007). Auditors' Liability in the European Union. European Company Law, 4(3), 103.

Beny, L. N. (2004). A Comparative Empirical Investigation of Agency and Market Theories of Insider Trading (p. 34). Discussion Paper, The Center of Law, Economics, and Business, Harvard University.

Cai, M. (2006). Study on Supervision Regulation of CPA (Master's thesis, Southwest University of Political science and Law, Chongqing, China). Retrieved from http://www.CNKI.net

Chan, D. K., \& Pae, S. (1998). An Analysis of the Economic Consequences of the Proportionate Liability Rule. Contemporary Accounting Research, 15(4), 457-480. http://dx.doi.org/10.1111/j.1911-3846.1998.tb00567.x

Chatfield, M. (1989). A History of Accounting Though (Wen, Shuo. Trans). Beijing: China Commercial Publishing House.

Directorate General for Internal Market and Services Annex II. (2007). Commission Staff Working Paper: Consultation on Auditors'Liability and its Impact on the European Capital Markets.

Davies, P. L. (1997). Gower's Principle of Modern Company Law (6th ed.). London: Sweet and Maxwell.

Easterbrook, F. H., \& Fischel, D. R. (1984). Mandatory disclosure and the protection of investors. Virginia Law Review, 669-715. http://dx.doi.org/10.2307/1073082

Firth, M., Mo, P. L., \& Wong, R. M. (2012). Auditors' Organizational Form, Legal Liability, and Reporting Conservatism: Evidence from China. Contemporary Accounting Research, 29(1), 57-93. http://dx.doi.org/10.1111/j.1911-3846.2011.01081.x

Johnston, G., \& Parker, C. (2007). Auditors' Liability in China-Tips on Managing Risks of Audit-Related Liabilities in China. A Plus June, 36-39.

Napier, C. J. (1998). Intersections of law and accountancy: Unlimited auditor liability in the United Kingdom. Accounting, Organizations and Society, 23(1), 105-128. http://dx.doi.org/10.1016/S0361-3682(97)00006-8

Wang, Z. (2002). The Effect of the Government's Requirement on the Audit Service Supply and Demand. The Chinese Certified Public Accountant, 29.

Wu, L. (2002). Research into the Risk Supervision of Securities Market. Nanjing: Jiangsu People's Publishing.

Xin, L. (2001). Analysis of the Theory of Asymmetric Information, Journal of Jiaxing College, 13.

Yi, C. (2003). An Empirical Study on the Privatization of CPA Firms and Their Subsequent Performance. China Accounting and Finance Review, 162.

Zhang, W. (2010). The Logic of the Market. Shanghai: Shanghai People's Press.

\section{Notes}

Note 1. http://www.csrc.gov.cn/pub/newsite

Note 2. Law of the People's Republic of China on Chinese-Foreign Contractual Joint Ventures(1979); The Income Tax Law of the People's Republic of China Concerning Chinese-Foreign Joint Ventures(1979).

Note 3. Rules for the Implementation of the Income Tax Law of the People's Republic of China Concerning Chinese-Foreign Equity Joint Ventures(1980, Art.20); Regulations for the Implementation of the Law of the People's Republic of China on Chinese-Foreign Equity Joint Ventures(1983, Art.90).

Note 4. Promulgating the Standards Concerning the Contents and Formats of Information Disclosure by Companies Offering Securities to the Public No1.-prospectus.

Note 5. Promulgating the Standards Concerning the Contents and Formats of Information Disclosure by Companies Offering Securities to the Public No11.-prospectus for the new shares.

Note 6. Art.16 of Measures for the Administration of the Issuance of Securities by Listed Companies. 
Note 7. Promulgating the Standards Concerning the Contents and Formats of Information Disclosure by Companies Offering Securities to the Public No.2-content and format of annual report.

Note 8. Art. 36 of Measures for the Administration of the Takeover of Listed Companies.

Note 9. http://www.iuscomp.org/gla/statutes/BGB.htm

Note 10. Supreme People's Court Interpretation (1997) No.10; Supreme People's Court Interpretation (1998) No.13. Supreme People's Court Interpretation (2002) No.21; Supreme People's Court Interpretation (2003) No.2; Supreme People's Court Interpretation (2007) No.12.

\section{Copyrights}

Copyright for this article is retained by the author(s), with first publication rights granted to the journal.

This is an open-access article distributed under the terms and conditions of the Creative Commons Attribution license (http://creativecommons.org/licenses/by/3.0/). 